\title{
OPOWIEŚĆ CIAŁA — CIAŁO OPOWIEŚCI JaK DOJRZEWAŁa SŁoWIAŃSKa EPOPEja JuliusZa SŁoWACKIEgo?
}

„Tak więc, kiedy ty dawne posągowe Rzymian postacie napełniasz wulkaniczną duszą wieku naszego, ja z Polski dawnej tworzę fantastyczną legendę, z ciszy wiekowej wydobywam chóry prorockie — i na spotkanie twojej czarnej, piorunowej, dantejskiej chmury prowadzę lekkie, tęczowe i ariostyczne obłoki [...]"1

— pisał w 1839 roku Słowacki do Krasińskiego w liście dedykacyjnym, poprzedzającym Balladynę, pierwsze ogniwo planowanych „kronik dramatycznych”. List zapowiada utwór lekki, kapryśny, w którym „instynkt poetyczny był lepszym od rozsądku”. W roku 1840 Słowacki skierował do tego samego adresata list poprzedzający Lille Wenedę. Jakże różne to listy! Lilla Weneda to już nie utwór z „ariostycznym” mrugnięciem oka, ale — jak stwierdził autor — rzecz podyktowana przez „mary krzyczące z krajów przeszłości”2. Dramat Wenedów, w przeciwieństwie do baśniowej Balladyny, jest mitem o początkach polskiego społeczeństwa. Kolejny dramat, o Kraku i Wandzie, nie powstał. Cykl kronik dramatycznych został zawieszony. Powrócił jako synteza genezyjskich wyobrażeń Słowackiego o słowiańskim świecie w poemacie Król-Duch.

W roku 1839 Słowacki zdecydował się na publikację powstałej pięć lat wcześniej Balladyny. Zadedykował ją Zygmuntowi Krasińskiemu, do którego skierował list poprzedzający dramat. Rozpoczyna się on anegdotą o ślepym harfiarzu, który śpiewał nad brzegiem Morza Egejskiego, sądząc, że szum fal to zgiełk tłumu, domagającego się pieśni. Gdy po skończonym występie pieśniarz nie otrzymał aplauzu, cisnął harfę w morze. Fale przyniosły instrument z powrotem na brzeg, lecz harfiarz odszedł zasmucony, nie wiedząc, że utopił w morzu najpiękniejszą pieśń. Poeta zasygnalizował, że ta historia „zastąpi wszelką do Balladyny przemowę"3. Słowacki — śpiewak, zyskawszy świadomość wartości rapsodu, postanowił nie topić swojej pieśni, lecz po-

\footnotetext{
*Magdalena Ciechańska - doktorantka w Katedrze Literatury i Tradycji Romantyzmu Uniwersytetu Łódzkiego. Pisze rozprawę na temat cielesności w twórczości Juliusza Słowackiego. Felietonistka i recenzentka internetowych serwisów czytelniczych „Opętani Czytaniem” oraz „Książki moja miłość”. Publikowała w pismach „Acta Universitatis Lodziensis. Folia Litteraria Polonica”, „Czytanie Literatury”, „Ryms”, „Kwartalnik Romski” oraz w tomach pokonferencyjnych Tekst - Tworzywo - Twórca i Świat zmystów.

${ }^{1}$ J. Słowacki, Balladyna. Tragedia w pięciu aktach, [w:] tenże, Dramaty (wybór), t. 1, Warszawa 1979, s. $252-253$.

${ }^{2}$ Zob. tenże, Lilla Weneda. Tragedia w pięciu aktach, [w:] tamże, s. 427.

${ }^{3}$ J. Słowacki, Balladyna, [w:] tamże, s. 251.
} 
kazać ją światu, wyposażywszy utwór w ariostyczny uśmiech i „wewnętrzną siłą urągania się z tłumu ludzkiego" ". Słowacki zapowiedział, że Balladyna będzie utworem przewrotnym, wyrafinowanym, łamiącym reguły. Legendarna jest już charakterystyka, którą poeta przedstawił w liście do matki, datowanym na 18 grudnia 1834 roku. Określił swoje dzieło jako nowatorskie, otwierające "nowy kraj poetyczny” i najlepsze, jakie do tej pory jego „mózgownica urodziła”. Próbując opisać dramat, mierzył się z problemem zdefiniowania jego charakteru. Pisał o podobieństwie do szekspirowskiego Króla Leara, stylizacji na opowieść gminną i całkowitej niezgodności z prawdą historyczną. Pięć lat później, w roku ukazania się Balladyny drukiem, Słowacki w liście dedykacyjnym do Krasińskiego nie wspominał już o motywach szekspirowskich, ale skupił się na osobie Autora. Balladyna jest wyrafinowaną grą, ale jest bardziej „zabawą w Balladynę, niż zabawą w Szekspira"'. Autor snuje się w świecie przedstawionym między swoimi marionetkami. Bawi się nimi i razem z nimi. „Słowacki, wprowadzając w utworze autorskiego sobowtóra, zmusza go do odgrywania ról, w których cielesność jest tworzywem służącym charakteryzowaniu postaci" ${ }^{7}$ — pisze Ewa Łubieniewska w swoich spostrzeżeniach na temat Beniowskiego. To stwierdzenie charakteryzuje również inne utwory poety. Autorskim sobowtórem Słowackiego w Balladynie jest Filon ${ }^{8}$, egzaltowany pasterz - poeta, który snuje się między postaciami dramatu, od sceny do sceny, pojawia się i znika, a zwracając się do publiczności (!), trzeźwo komentuje zastaną rzeczywistość, mimo że sprawia wrażenie niegroźnego wariata. Pierwsze słowa, które padają pod adresem tej postaci, zaraz po jej wejściu na scenę to pełna oburzenia wypowiedź Pustelnika:

\section{PUSTELNIK \\ Co znaczą owe narzekania zrzędne? \\ Młody szaleńcze, gdzie zimny rozsądek? \\ Wywracasz świata boskiego porządek ${ }^{9}$. \\ [podkreślenie moje - M.C.]}

Filon wywraca „świata Boskiego porządek” zupełnie, jak przystało na bohatera/autora dramatu, który „ma moc urągania się z porządku i ładu, jakim się wszystko dzieje na świecie" ${ }^{\prime 1}$.

\footnotetext{
${ }^{4}$ Tamże, s. 251.

${ }^{8}$ Zob. L. Libera, dz. cyt., s. 16-17.

${ }^{9}$ J. Słowacki, Balladyna..., s. 263.

${ }^{10}$ Tamże, s. 251.
}

${ }^{5}$ Zob. J. Słowacki, Korespondencja, oprac. E. Sawrymowicz, t. 1, Wrocław 1962, s. 273.

${ }^{6}$ Zob. L. Libera, Zraniona iluzja. O „Balladynie” Juliusza Stowackiego i „Kocie w butach” Ludwiga Tiecka, Zielona Góra 2007, s. 21. O motywach Szekspirowskich w Balladynie zob. W. Weintraub, „Balladyna” czyli zabawa w Szekspira, „Pamiętnik Literacki” 1970, nr 4, s. 45-89.

${ }^{7}$ E. Łubieniewska, Performer z Krzemieńca, [w:] Poemat dygresyjny Juliusza Stowackiego. Struktura, konteksty, recepcja, red. M. Kalinowska i M. Leszczyński, Toruń 2011, s. 93. 
„Zabawa w Balladynę" to nie tylko niszczenie porządku świata i łamanie zasad literackich. Ta zabawa to również gra z ciałem. Cielesność jest ważnym aspektem dramatu. Autor - Filon stwierdził:

\section{FILON}

Nudzi mię ten stary,

W głowie ma jakieś bezcielesne mary, [podkr. - M.C.]

Pewnie oszalał samotnością, postem ${ }^{11}$.

„Bezcielesne mary” nie mają w świecie Balladyny racji bytu. Mglista Goplana może jedynie tęsknić za miłością człowieka, a i w konstrukcji utworu jej rola szybko się wyczerpuje. Goplana zainicjowała intrygę, która wymknęła się spod jej kontroli, a potem zaplanowała karę dla Balladynę, zupełnie wbrew logice własnych interesów ${ }^{12}$. Goplana jest konstrukcyjnie niespójnym elementem dramatu. Być może jest personifikacją kapryśnej poezji romantycznej, ilustracją bujnej fantazji poety ${ }^{13}$. W pewnym momencie Słowacki zdecydował się pożegnać zagubioną w intrydze nimfę i wysłać ją gdzieś na północ, rekompensując to efektowną sceną pożegnania ${ }^{14}$.

Jeśli jednak coś nie pasuje, tym bardziej należy się temu przyjrzeć. Goplana - reżyserka jest początkowo postacią przerysowaną, zabawną w swojej głupocie i naiwności. Poeta stworzył w ten sposób parodię romantycznej rusałki - świtezianki. Nakazał jej zakochać się w nieokrzesanym chłopie, który w jej subtelności widział galaretowatość meduzy, a zaloty nimfy przyprawiały go o mdłości. Goplana nie grzeszyła przy tym intelektem. Nie potrafiła zinterpretować wymijających odpowiedzi Grabca, który nie zamierzał początkowo nawet wyjawić swojego imienia:

\section{GOPLANA}

Jak się nazywasz, piękny młodzieńcze?

GRABIEC

Nic sobie...

GOPLANA

Miły nic sobie! $!^{15}$

\footnotetext{
${ }^{11}$ Tamże, s. 264.

${ }^{12} \mathrm{O}$ niespójnym zachowaniu Goplany zob. L. Libera, $d z$. cyt., 32-33, 42-43.

${ }^{13}$ Zob. M. Janion, Obrona Balladyny, [w:] taż, Odnawianie znaczeń, Kraków 1980, s. 138.

${ }^{14}$ Por. J. Ławski, Ironia i mistyka. Doświadczenia graniczne wyobraźni poetyckiej Juliusza Stowackiego, Białystok 2005, s. 388: „Poplączą ludzkie losy [Goplana, Skierka, Chochlik] — jako wielkie i śmieszne zarazem Figury Wyobraźni - by ulecieć... Dokąd? Znikną z tego świata, by pogrążyć się w wyobraźni Poety, skąd wyszły".

Interesująco pisze na ten temat także K. Korotkich. Badacz widzi w odejściu Goplany najwyższą formę ironii - personifikacja Wyobraźni nie może znieść praw, które obowiązują w wyobrażonym świecie. Zob. K. Korotkich, Wyobraźnia apokaliptyczna Juliusza Stowackiego. Obrazy - wizje - symbole, Białystok 2011, s. 320-321.
}

${ }^{15}$ J. Słowacki, Balladyna..., s. 272. 
Grabiec skwitował tę scenę komentarzem: „Jakżeś głupia, mościa pani” i spróbował wykorzystać jakoś awanse nimfy, choćby szukając w niej odrobiny erotyzmu. Goplana uważała wszelki cielesny kontakt za utratę czystości i wieczysty ślub. Grabiec widział to zgoła inaczej. Zamierzał „skosztować” i czekać na rozwój sytuacji. Doszło do pocałunku, który niemalże doprowadził Grabca do torsji:

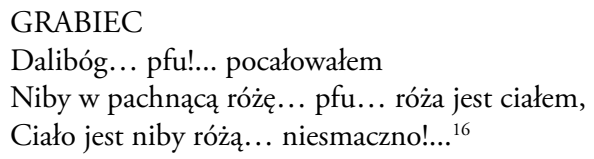

GRABIEC

Dalibóg... pfu!... pocałowałem

Niby w pachnącą różę... pfu... róża jest ciałem,

Ciało jest niby różą... niesmaczno!... ${ }^{16}$

Goplana, sądząc że jest już na wieki zaślubiona Grabcowi, snuła plany długiego i szczęśliwego pląsania w goplańskich falach. Grabiec zaś bez skrupułów oświadczył, że udaje się wieczorem na schadzkę z Balladyną. Nie szczędził nimfie przykrych słów na temat jej aparycji: „dziwne stworzenie z mgły i galarety”, „widzę coś rybiego w tej dziwnej osobie”, „zmora, koczkodan”... Goplana nie rozumiała, z jakiego powodu została odrzucona i przysięgła, że poruszy wszystkie potęgi, aby być z kochankiem. Nie pojmowała, że na nic zda się jej czyste serce, skoro to właśnie Balladyna „ma piękną nóżkę". Tragedia Goplany polega na tym, że warunkiem jej materialnego istnienia jest miłość tego, którego obdarzyła uczuciem. Nimfa wymyśliła zgubną w skutkach intrygę, aby móc zachować materialną postać. W obliczu miłosnego zawodu królowa Gopła zaplanowała wyrafinowane samobójstwo - przeistoczenie się w mgłę, która opadnie i zginie na zawsze. Rozpacz nimfy osiągnęła apogeum, gdy dowiedziała się ona o nocnej schadzce Grabca i Balladyny. W płomiennym monologu Goplana przede wszystkim dała upust poczuciu bezsilności i zawiści wobec pięknej rywalki. Zazdrościła jej ponętnego ciała, czaru, uwodzicielskich spojrzeń. „Żeby ta dziewa jedno spojrzenie mi/ Przedała dzisiaj za brylanty światów..."17 — rozpaczała Goplana. Chciała za wszelką cenę połączyć się fizycznie z kochankiem, choćby pod postacią powoju, który miałby opleść jego ciało. Ostatecznie zdecydowała się zmienić Grabca w wierzbę, aby nauczyć go „kochać i płakać" ${ }^{18}$. Lekcja nie przyniosła pożądanego skutku, zatem Goplana została usunięta ze sceny.

Inną „bezcielesną” postacią, która musi opuścić teatr, jest Alina. Młodsza siostra to modelowa królewna z bajki. Niemalże doskonale pasuje do teatralnej koncepcji Słowackiego - jest czysta, niewinna, piękna jak anioł, słodka i uczynna, a w dodatku przybywa po nią bajkowy królewicz i to jej dobroć i prostolinijność zostają nagrodzone bogactwem malin. Jej wadą jest świadomość koncepcji teatralnej ${ }^{19}$. Autor wyposażył tę postać w wiedzę metaliteracką, w związku z czym wie ona, że ma pokochać Kirkora, sprowokować siostrę i zginąć z uśmiecham na ustach. W przeciwieństwie do siostry,

\footnotetext{
${ }^{16}$ Tamże, s. 274.

${ }^{17}$ Tamże, s. 296.

${ }^{18}$ Tamże, s. 298.

${ }^{19}$ Zob. L. Libera, dz. cyt., s. 31.
} 
Alina jest jakby przezroczysta. Wiemy, że ma różaną cerę, fiołkowe oczy i że jest ,jako złote na zorzy aniołki" ${ }^{20}$. Alina zyskała ciało dopiero, kiedy stała się trupem i jedynie w tym sensie jest obecna w kolejnych scenach utworu. Cielesność Balladyny jest natomiast niezwykle wyrazista, do tego stopnia, że jej ciało zapisało zbrodnię, którą popełniła. Przerażona morderczyni stwierdziła: „Wszystkie mi włosy przesiąkły sumnieniem i ciągną nazad wstając z głowy"21. Oprócz tego, na jej czole pojawiła się krwawo-malinowa plama, której nie dało się usunąć. Co ciekawe, Balladyna widziała jedyną przeszkodę w pamięci ciała, bo „rozum już przywykł” do myśli o morderstwie.

Czemu jednak służy takie zaakcentowanie cielesności starszej siostry? Wszak nie jest to znak jej silnego charakteru i samodzielności. Balladyna jest może najbardziej bezwolną z kukieł dramatu — zamordowała, bo świadoma konwencji Alina nakłoniła ją do tego, a potem była już tylko marionetką w intrydze Fon Kostryna. Gdy wydała na siebie wyrok, również postąpiła tylko zgodnie z odgórnymi regułami (takie jest prawo!). Gdy przyjrzymy się dokładniej konstrukcji dramatu, zauważymy, że oprócz wątku patriotycznego i wypadków z koroną Popielów, jedyną siłą napędową akcji jest miłość i seksualność: Goplana kochała Grabca, Grabiec wolał nóżkę ponętnej Balladyny. Z tego schematu wynikają kolejne zdarzenia, intrygi i zbrodnie.

W roku 1840 została wydana kolejna część „kronik dramatycznych”, Lilla Weneda. „Mów o nas prosto i z krzykiem” — poetycko relacjonował Słowacki w liście dedykacyjnym do Zygmunta Krasińskiego prośbę wenedyjskich duchów. Jest to zapowiedź zmiany optyki poetyckiej w stosunku do Balladyny. Słowacki podkreślił, że nowy utwór jest „mniej fantastyczny”, lecz „szerszy”, „bardziej tęczowy” i przybiera formę „pół-posągowej” tragedii Eurypidesa ${ }^{22}$.

Słowacki zaproponował następujący typ lektury: „usiądź [...], abyś z książką moją mógł to zrobić, co zamyślona z białą różą w ręku dziewczyna; to jest oberwać ją liść po liściu, rzucić w wodę płynącą i pytać się losu listków o los człowieka; a zniszczywszy tak ciało Lilli Wenedy, odtwórz ją na nowo w myśli swojej [...] i niech ta postać do nas obu należy [...]"23 podkreślenie moje - M.C.]. Warto zaryzykować odczytanie propozycji Słowackiego dosłownie i potraktować tworzenie i odczytywanie dzieła literackiego jako proces budowy i niszczenia ciała.

Córka Derwida pozornie przedstawiona została jako istota „przezroczysta”. Jej ciało jest opisane dopiero w scenie śmierci. Trup Wenedyjki stał się przedmiotem zachwytu jednej z dziewcząt służebnych Gwinony. Opisała ona ciało Lilli jako „bielutkie” niczym gołąb, powoli błękitniejące po śmierci, zachwyciła się jej krągłymi piersiami i drobnymi nóżkami. Nie jest to jednak jedyny moment, kiedy podkreślona jest cielesność wenedyjskiej królewny. W momencie pożegnania Lilli i Lelum, którzy są jednocześnie rodzeństwem i parą narzeczeńską, mężczyzna próbował rozbudzić po raz ostatni seksualność dziewczyny, która już mieniła się „narzeczoną śmierci”:

\footnotetext{
${ }^{20}$ J. Słowacki, Balladyna..., s. 285.

${ }^{21}$ Tamże, s. 308.

${ }^{22}$ Zob. Tenże, Lilla Weneda..., s. 427.

${ }^{23}$ Tamże, s. 429-430.
} 
Więc rozpuść, Lillo, twoje złote włosy,

Schowaj się za nie jako za strunami

Harfy ojcowskiej... niechaj przez warkocze

Twych koralowych ust dotknę ustami... ${ }^{24}$.

Lilla odmówiła pocałunku i odeszła. Powróciła ubrana w biel, z wieńcem lilii na głowie. Był to strój przypisany zwyczajowo zmarłym wenedyjskim dziewicom. Dziewczyna po długich błaganiach została wpuszczona do morzonego głodem ojca. Liliowy wianek posłużył za pokarm umierającemu Derwidowi, ale znaczenie tej sceny jest wymownie symboliczne. Lilla wyszła z wieży, w której więziony jest ojciec, bez wianka na głowie, co znaczy, że wiele poświęciła. Nie wymaga komentarza ani oczywista konotacja imienia Lilla z nazwą kwiatu, ani skojarzenie wianka z czystością i niewinnością. Scena staje się jeszcze bardziej wymowna w świetle kolejnych wydarzeń. Derwid musiał dokonać wyboru — mógł albo ocalić córkę, albo harfę — symbol jego władzy, narzędzie zwycięstwa, jak wierzyli Wenedzi, a także symbol potęgi pieśni. Córka od początku wiedziała, że zostanie poświęcona dla ocalenia harfy. Zgodziła się na utratę czci i śmierć. Symbolem dobrowolnego poświęcenia jest oddany ojcu liliowy wianek — Lilla została pożarta, pochłonięta jak lilie. Dziewczyna zrobiła wszystko, aby wybór ojca padł na bezcenną harfę. Umniejszyła swoją wartość, wobec wartości poezji:

Ja wiem, że ty mnie kochasz, ojcze drogi

Lecz nie wybieraj mnie, bo nieszczęśliwy,

Jeżeli zechcesz o nieszczęściu śpiewać,

To znajdziesz we mnie tylko echo płaczu,

A w harfie echo nieśmiertelne ${ }^{25}$.

Mimo że Lilla cierpiała i wspominała „pocałunki ojca w ciemnym więzieniu”26, złożone na jej ustach i włosach (których nie pozwoliła całować bratu-narzeczonemu), zgodziła się na śmierć dla ocalenia harfy. Ostatecznie Lilla została uduszona przez Gwinonę, rozwścieczoną stratą ukochanego syna. Morderczyni w momencie popełnienia zbrodni nazwała królewnę „harfiarką”. Ukoronowaniem tragicznego losu młodej Wenedyjki było zastąpienie magicznej harfy jej ciałem. Trupa dziewczyny złożono w skrzyni i odesłano jako dowód dotrzymania warunków umowy między Wenedami a Lechitami. Zamiast obiecanej przez Rozę pieśni zwycięstwa, Derwid dał swemu ludowi pieśn rozpaczy. Instrumentem dla tragicznego rapsodu było martwe ciało Lilli. Król Wenedów rozplótł warkocze zmarłej i dotykał jej włosów niczym strun harfy. Pieśnią był jego lament nad ciałem ukochanej córki. Wenedyjski król, widząc zagładę ludu, utratę siły poezji i śmierć Lilli, przebił się dwukrotnie nożem ofiarnym. Roza natomiast przygotowywała swój lud na zbiorowe samobójstwo.

\footnotetext{
${ }^{24}$ Tamże, s. 478.

${ }^{25}$ Tamże, s. 508.

${ }^{26}$ Tamże, s. 510.
} 
Próba odczytania Lilli Wenedy na płaszczyźnie metaliterackiej wymaga założenia, że treścią dramatu jest nie tylko zagłada Wenedów i mit założycielski, ale także sam proces twórczy. Słowacki zdaje się dawać na to pełne przyzwolenie. „Zniszcz ciało Lilli Wenedy i odtwórz ją na nowo w myśli" ${ }^{27}$ — pisał do Krasińskiego-czytelnika. W świetle tych słów Lilla Weneda jest także utworem o recepcji twórczości literackiej i samym procesie twórczym. Utwór literacki staje się ciałem, które w wenedyjskim dramacie jest męczone, torturowane w sposób wymyślny i wyrafinowany, aż podlega ostatecznej zagładzie na stosie ofiarnym. Przy życiu pozostała makabryczna wieszczka wenedyjska, która przez cały utwór aranżowała godne unicestwienie swojego ludu, z kluczową rolą pieśni w tym spektaklu zagłady. Czy jest to tylko zagłada szlachetnego narodu, podbitego przez okrutny i mściwy lud? Temu narodowi przytrafiały się rzeczy absolutnie nieprawdopodobne. Natężenie okrucieństwa tortur, kazirodczych relacji między bohaterami, doprowadzone do absurdu w scenie zapładniania się Rozy popiołami poległych, okraszone niewybrednymi komentarzami Ślaza (w którym notabene niektórzy badacze dopatrują się postaci samego autora) sprawia, że została przekroczona granica makabry i śmiechu. Poeta zasugerował tym samym, że mamy do czynienia z teatrem, z literackością, z fikcją. Czyżby autor znów puszczał do nas oko i przestrzegał: uważaj czytelniku? Być może, lecz nie jest to już „ariostyczne mrugnięcie”. Słowacki pisał: „zniszcz i stwórz”. Nazwanie utworu ciałem ma swoje konsekwencje. Zaczyna on żyć, pulsować, mnożyć się. To wyraźna zapowiedź nowego typu lektury i nowego sposobu kreowania dzieła, w którym autor daje ogromną władzę czytelnikowi i oczekuje od niego poszukiwania pęknięć, szczelin, przez które można dostrzec różne możliwości odczytania tekstu.

Cykl kronik dramatycznych nie powstał. Słowacki stworzył baśń i mit założycielski. Syntezą dziejów Polski miała być epopeja słowiańska, poemat Król-Duch. Wiąże się on tematycznie z Lillą Wenedą. Król-Duch jest zapowiadanym mścicielem i synem Rozy, narodzonym z popiołów poległych wojowników.

Odczytywano Króla-Ducha na wiele sposobów, przede wszystkim poprzez filozofię historii, jako utwór obrazujący pewne prawidłowości w dziejach Polski. Winiono autora za niekonsekwencje fabularne, zarzucano mu potknięcia gramatyczne i „,nieskładność”. Postrzegano poemat jako niedokończony, nieuporządkowany, niemożliwy do „logicznego złożenia”28. Pawlikowski wspominał o chaosie rękopisów, które były składane dosyć przypadkowo lub według pomysłu wydawcy ${ }^{29}$. Wygląd rękopisów oraz ich opis, dokonany przez Pawlikowskiego, daje pewne wyobrażenie o ogromie pracy, jaki należy włożyć w odczytanie poematu. Tekst jest kreślony, poprawiany, partie utworu zostają porzucone, do niektórych autor powraca, zmienia, pisze na tekście, we wszyst-

\footnotetext{
${ }^{27}$ Tamże, s. 429-430.

${ }^{28}$ Zob. M. Sokołowski, „Król - Duch” Juliusza Stowackiego a epopeja stowiańska, Łódź 2004, s. 9.

${ }^{29}$ Zob. J. G. Pawlikowski, Komentarz, [w:] J. Słowacki, Król — Duch, wydanie zupełne, komentowane. Ułożył i komentarzem opatrzył J. G. Pawlikowski. Brzmienie tekstów z rękopisów ustalił M. Pawlikowski, t. 2, Lwów 1924 [właśc. 1924], s. 8-9.
} 
kich możliwych stronach, nie wykluczając kierunku dół — góra, co kłóci się z naczelną zasadą konstruowania tekstów w różnych systemach pisma na świecie ${ }^{30}$.

W ostatniej dekadzie ubiegłego stulecia pojawiła się refleksja, że może nie należy tracić energii na szukanie klucza do logicznego uporządkowania treści, że może zamysł Słowackiego znacznie przekracza nasze wyobrażenia o organizacji, kształcie tekstu i sposobie jego czytania, mimo że mamy za sobą doświadczenie wielkich narracyjnoformalnych eksperymentów literatury XX wieku' ${ }^{31}$.

Najbardziej zagadkowy poemat w dorobku Juliusza Słowackiego rozpoczyna się od refleksji nad ciałem, którego nie chce porzucić zaleniwiony duch Herra Armeńczyka:

Wtenczas to dusza wystąpiła ze mnie,

I o swe ciało już nie utroskana,

Ale za ciałem płacząca daremnie

(R I, p. 1) $)^{32}$

A gdyby zatem odczytać Króla-Ducha jako poemat-ciało? Idąc za refleksją Mikołaja Sokołowskiego nazywam „odmiany tekstu” „odnogami” lub „rozgałęzieniami””33. Badacz dostrzegł w utworze strukturę organizmu, monadę, którą wypełniają w nieskończoność inne monady. Daje to niezwykle szerokie możliwości badawcze. Takie założenie pozwala sądzić, że nie ma w Królu-Duchu fragmentów zbędnych, ani nie istnieje w nim logiczna ciaggłość fabuły. Utwór nie ma wyraźnego początku i zakończenia, co świadczy o tym, że Słowacki uznał je za nieważne. Poemat rośnie „od środka”, wibruje, pączkuje, rozgałęzia się jak żywy organizm. Zastanawiająca pod tym kątem wydaje się uwaga Pawlikowskiego na temat rękopisów:

Słowacki w owym okresie swojego życia żył niby w atmosferze Króla Ducha, w atmosferze anamnezy swych metempsychicznych przeżyć. Myśl jego wciąż obracała się w tym kole, a tak jak w marzeniach powracamy wciąż do tych samych obrazów, które nas zajmują, tak on powracając do nich ujawnia je równocześnie piórem. Rękopisy Króla Ducha przedstawiają się niby grafikony aparatów regestrujących w jakimś laboratorium psycho-fizjologicznym, grafikony ujawniające w niespodziany i zadziwiający sposób procesy duchowe z natury niewidzialne dla oka. Ta bezpośredniość w uzewnętrznianiu się procesu twórczego nadaje tym rękopisom szczególne znaczenie psychologiczne i czyni z nich niezwykle interesujący przedmiot badań ${ }^{34}$.

Na tym urywa się „psycho-fizjologiczna” opinia Pawlikowskiego i badacz przeszedł do uwag na temat znaczenia wyglądu rękopisów dla pracy edytora. Zaznaczył

\footnotetext{
${ }^{30}$ Zob. M. Sokołowski, dz. cyt., s. 110-111.

${ }^{31}$ Zob. refleksje Marty Piwińskiej zawarte w znakomitym studium Juliusz Stowacki od duchów, Warszawa 1992.

32 J. Słowacki, Król - Duch, [w:] tenże, Dzieła wszystkie, red. J. Kleiner, t. 7, oprac. J. Kleiner, Wrocław 1956, s. 5.

${ }^{33}$ Zob. M. Sokołowski, dz. cyt., s. 105.

${ }^{34}$ J.G. Pawlikowski, dz. cyt., s. 15.
} 
przy tym, że poznanie „aury” tego poematu nie jest możliwe bez wejścia w świat odmian tekstu ${ }^{35}$.

Zatrzymajmy się przy „laboratorium psycho-fizjologicznym”. Dołóżmy powtarzającą się jak mantra uwagę badaczy, że Słowacki nie zdążył uporządkować utworu. Na kartach rękopisów widać przebieg procesu twórczego, lawinę myśli i.... niewyobrażalną chęć ZAPISANIA. W rękopisach dostrzec można również, że Słowacki próbował zapełnić każdą wolną przestrzeń karty. Pawlikowski wspomniał o „dziwnym nałogu” poety - zwyczaju zapisywania każdego wolnego marginesu oraz o nagłym przerywania kilku spójnych strof zupełnie innym pomysłem, zapisanym jakby z rozmachu, tym samym pismem, $\mathrm{z}$ tym samym impetem, prawdopodobnie $\mathrm{w}$ tym samym czasie ${ }^{36}$. W gorączce, która jak twierdził Słowacki, dodawała mu sił, notował on wszystko, co urodziła jego wyobraźnia. Dowodów na chęć zapisania wszystkiego dostarcza nie tylko kształt rękopisów. W poemacie mnóstwo jest miejsc, w których poeta stworzył wrażenie symultaniczności zdarzeń, a także jednoczesnego wypowiadania dwóch myśli. Nie sposób również czytać utwór linearnie. Odpowiednie patie „tekstu głównego” należy uzupełnić lekturą „odmian”. W przeciwnym razie — jak pisał Pawlikowski - czytelnik nie ma szans na posmakowanie aury Króla-Ducha.

Zastanawiająca jest jeszcze jedna z manier Słowackiego, mianowicie kropkowanie stron, „tak jakby niecierpliwe pióro nie mogło spocząć, kiedy myśl nadążyć mu nie może" ${ }^{37}$ lub — dopowiedzmy — jakby poeta za wszelką cenę chciał zapisywać, w każdej minucie procesu twórczego zaznaczać swoją obecność lub przekonywać samego siebie o własnym materialnym istnieniu. Warto w tym momencie wspomnieć wzruszającą scenę śmierci Ellenai z Anhellego. Pragnęła ona przede wszystkim istnieć materialnie, jako ciało, które oddycha i czuje. Kobieta w rozpaczy śmierci wypowiedziała słowa: „Oto chciałabym być jaką rzeczą żyjącą przy tobie” ${ }^{38}$. Tego rodzaju tendencje nasilały się w późnej twórczości Słowackiego. To niezwykle przejmujące, biorąc pod uwagę systematycznie pogarszający się stan zdrowia poety. Istotnie, mógł nie zdążyć poematu uporządkować. Szczęsny Feliński w opisie ostatnich dni życia Słowackiego wspomniał o poemacie, którego poeta nie miał siły pisać i który przez jakiś czas mu dyktował. Ale czy po ewentualnym uporządkowaniu poemat byłby „przystępniejszy”? Możliwe, że szczeliną, wiodącą do interpretacji Króla-Ducha, jest kontrast pomiędzy niezwykle rozbudzoną imaginacją, a ciałem, które stawia bariery. Być może to właśnie sprawiło, że powstał tekst, który pulsuje, mnoży się i pączkuje jak żyjące ciało.

\footnotetext{
${ }^{35}$ Zob. tamże, s. 15.

${ }^{36}$ Tamże, s. 14-15.

${ }^{37}$ Tamże, s. 13. Zachowałam oryginalną interpunkcję.

${ }^{38}$ J. Słowacki, Anhelli, [w:] tenże, Poematy. Nowe wydanie krytyczne, oprac. J. Brzozowski i Z. Przychodniak, t. 1, Poznań 2009, s. 441.
} 
Magdalena Ciechańska

\section{The Story of the Body - The Body of THE Story \\ How Matured Juliusz Slowacki's Slavic Tale?}

\section{Summary}

The aim of the article is to present an evolution unrealized of Juliusz Słowacki's creation the "dramatic chronicles". The variations about Polish nation's fairy-tale and Slavic World's past matured in the Słowacki's mind from 'Ariosto style' of Balladyna, through a drama Lilla Weneda, to the story of the King-Ghost who wanders through successive incarnations. The Słowacki's idea has evolved since the theatrical story, in which the poet leads a sophisticated game with the reader, to the mistical poem with desire to write about the universe and the laws running it. One of the main points of the analysis will be an aspect of physicality and suffering in the above mentioned works and their relation with deteriorating Juliusz Słowacki's physical condition.

Słowa kluczowe: Juliusz Słowacki, romantyzm, ciało, Słowiańszczyzna, rękopisy

Keywords: Juliusz Słowacki, Romanticism, body, Slavdom, manuscripts 